\title{
Economic parameters and quality assessment of lignite from the Szczerców deposit (central Poland)
}

\author{
Sandra Pawelec \\ AGH University of Science and Technology, Faculty of Geology, Geophysics and Environmental Protection; \\ al. Mickiewicza 30,30-059 Krakow, Poland; e-mail: spawelec@agh.edu.pl
}

(C) 2016 Authors. This is an open access publication, which can be used, distributed and reproduced in any medium according to the Creative Commons CC-BY 4.0 License requiring that the original work has been properly cited.

Received: 2016-07-06; accepted: 2017-01-05

\begin{abstract}
Bełchatów Lignite Mine is the largest producer of lignite in Poland with estimated coal reserves of 700 million tons. The mine excavates two lignite deposits Bełchatów and Szczerców. The Szczerców lignite deposit occupies the western part of the Kleszczów trough, located in the Polish Lowlands. The main part of the lithostratigraphic profile of the Szczerców lignite deposit is a multilayer coal complex, whose thickness varies from 1 to $180 \mathrm{~m}$, with the overburden ratio of 2.84:1. The average thickness of the balance lignite amounts to $40 \mathrm{~m}$. The carbonaceous coefficient of the coal complex in the predominant part of the deposit is over $70 \%$, but locally reaches even up to $100 \%$.

Lignite from the Szczerców deposit is of an average technological quality. It typically contains $51.7 \%$ of total moisture, $23.6 \%$ of ash on dry basis, $3.36 \%$ total sulphur recalculated to dry basis, and a net calorific value of $7.33 \mathrm{MJ} / \mathrm{kg}$. Random reflectance $\left(\mathrm{R}_{0}\right)$ is $0.27 \%$ with huminite group macerals averaging at $85 \%$. According to the International Classification of In-Seam Coals and Low Rank Coal Utlization, the technological code of the lignite from the Szczerców deposit is: humic low-rank C (orto-lignite) 195123 33. Similarities between the quality parameters of lignite from the Szczerców and Bełchatów deposits will allow it to be burned in the Bełchatów lignite-fired power plant and may give a chance to extend its activity after the completion of lignite mining from the Bełchatów deposit.
\end{abstract}

Keywords: Miocene of Poland, lignite, Szczerców lignite deposit, technological and geological criteria, quality assessment, economic assessment

\section{INTRODUCTION}

Currently, coal is one of the primary energy sources in Poland. In addition, an upward trend in the production of lignite and electricity from this raw material can be observed in recent years. For many years, the Bełchatów Lignite Mine (with the Bełchatów and Szczerców deposits) has been the largest producer of lignite in Poland. The history of coal mining in the Bełchatów deposit dates back to 1980 . However, it is expected that coal mining in the largest coal deposit in Poland will end until the year 2020. Currently, lignite from the Bełchatów deposit is extracted from progressively deeper parts of the coal complex up to $110 \mathrm{~m}$ b.s.l. It is the only mine in the country to carry out opencast mining at such depths. Due to the fact that coal seams in the Bełchatów deposit are being depleted, every year more and more lignite is produced from the Szczerców deposit located $15 \mathrm{~km}$ away (Kasztelewicz 2004). Therefore, it can be assumed that, after the depletion of the Bełchatów opencast mine, the Szczerców deposit will be the only one to supply lignite to the Bekchatów power plant for at least 10 years. Hence, technical analysis of lignite is crucial for assessing the suitability of this raw material for the energy sector. 
The Szczerców deposit is located in the ŁódźBełchatów region, in central Poland (Fig. 1). The aforementioned deposit is located in the southern part of the Middle Polish synclinorium, within the Kleszczów graben (Narkiewicz \& Dadlez 2008) (Fig. 1). It is separated from the Bełchatów deposit by the Dębina Salt Dome in the east, while thickness of lignite-bearing sediments is gradually decreasing towards west. The boundaries of the deposit in the north and south are defined by the fault edges of the Kleszczów trough (e.g. Peryt \& Piwocki red. 2004, Widera 2013).

The Bełchatów Lignite Mine started the mining of lignite in the Szczerców's in August 2009, using an opencast and longwall method. The
Bełchatów mine and the Bełchatów power plant together form the largest mining and electricity complex in the whole of Europe. Annual production is 38.5 million tons of lignite per year, with a removal overburden of about 100-120 million $\mathrm{m}^{3}$ (Pietraszewski 2015). Along with lignite, sand, gravel and lacustrine chalk are mined as well (Adamczyk et al 2012). The deposit's surface area is $1369.3 \mathrm{ha}$, and it is planned to establish 14 mining levels, including 6 levels of lignite exploitation. The recoverable resources of lignite are estimated at 662.3 million tons at the end of 2014, whose extraction is planned until 2037 (Pietraszewski 2015, Szuflicki et al. 2015, Widera et al. 2016).

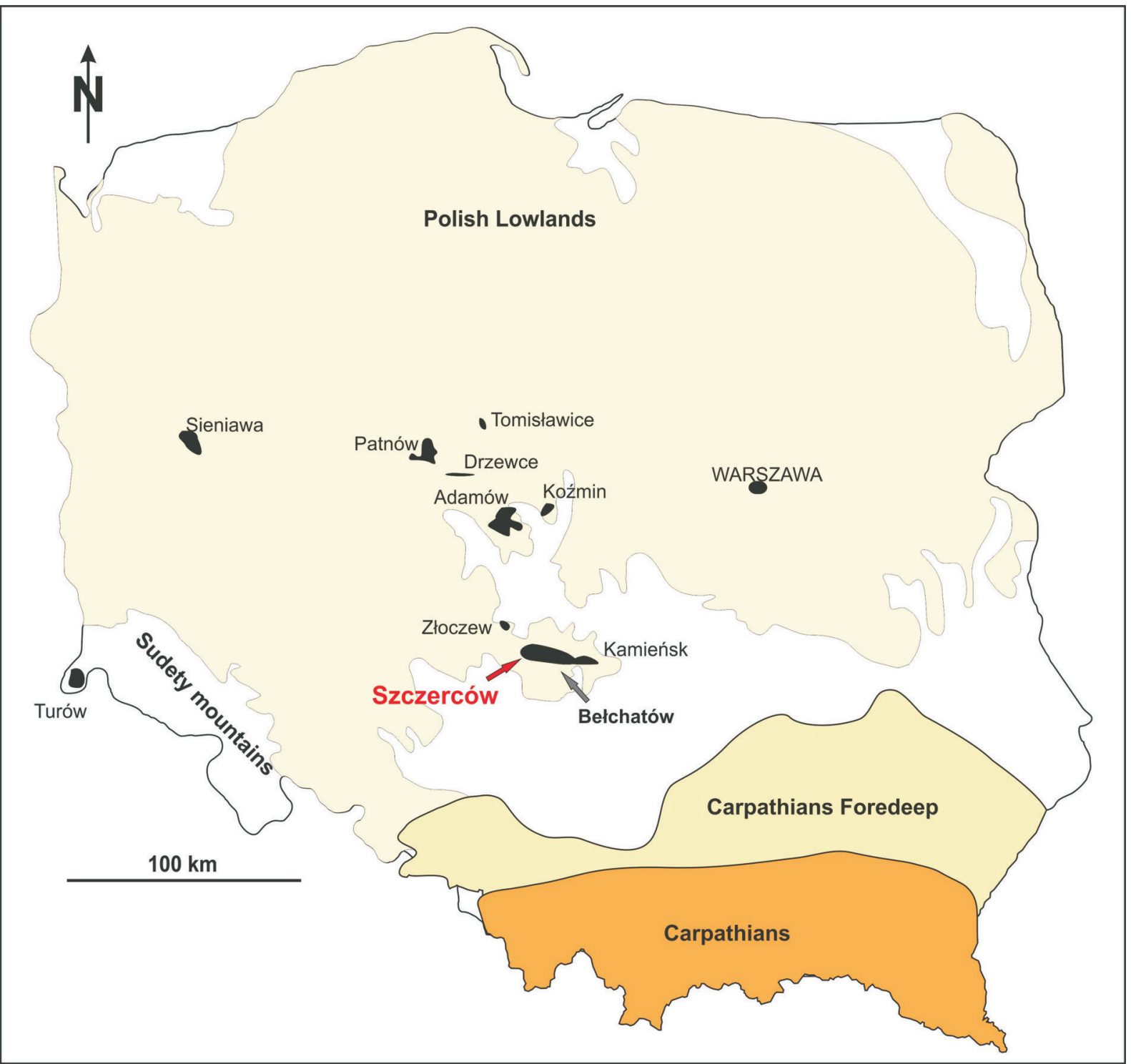

Fig. 1. Tertiary map of Poland showing location of lignite deposits, modified from Kasiński (2000) 
The end of mining in the Szczerców area is expected to be in 2038 due to the complete extraction of the lignite; while those related to the shallowing of mining pits will be completed in the year 2050. Finally, it is planned to carry out postmining reclamation works for water purposes until 2100 (Kozioł \& Sośniak 2011).

The primary aim of the present paper is to characterize the basic economic and technological parameters of lignite from the Szczerców deposit. In the future, such analysis can lead to improving the process of lignite acquisition and its use. This could minimize the operating costs during increasing extraction of lignite and reduce the risk of mining activities for the environment.

\section{GEOLOGY}

The Kleszczów trough, is located in the Cretaceous and Jurassic basement, is of the Laramie orogeny age. It is about $40 \mathrm{~km}$ long and from $1.5 \mathrm{~km}$ to $3 \mathrm{~km}$ wide (Ciuk 1980, Gotowała \& Hałuszczak 2002). It extends from the Pajęczno region in the west to the vicinity of Przedbórz in the east. It creates the boundary between the Radomsko Hills in the south and the Łódz Sinclinorium in the north (Narkiewicz \& Dadlez 2008). The Kleszczów trough is not symmetrical tectonic structure, because it is deeper in the northern part than in its southern part. As a result, the northern part is characterized by the varied morphology of its bottom. The current depth of the Szczerców opencast is about 200-300 m; while the total depth of the Kleszców trough exceeds
$500 \mathrm{~m}$. It is limited by the fault edges of the Mesozoic top in the area of the Szczerców lignite deposit (e.g. Gotowała \& Hałuszczak 2002, Peryt \& Piwocki red. 2004, Widera \& Hałuszczak 2011, Widera 2013). The oldest sediments known from the Kleszczów trough area are of Zechstein age and are related to the Dębina Salt Dome. The basement of the Paleogene and Neogene sediments forms the Late Jurassic karstified limestones and the Late Cretaceous gaizes. The caverns within the limestones contain intercalations of the gelitic lignite that fills fault fissures and voids in the weathered limestones (Wagner 2001). It was formed with the participation of gravitational flows related to damage the $5^{\text {th }}$ Czempin lignite seam (CLS-5). It is of Early Oligocene age (Widera 2016). The maximum thickness of the aforementioned gelitic lignite intercalations reaches up to $5 \mathrm{~cm}$ (Wagner 2001).

The lignite-bearing sediments, which are of Neogene age, are traditionally divided into four lithostratigraphic complexes: sub-coal complex, coal complex, clay-coal complex and clay-sandstone complex (Fig. 2) (Czarnecki et al. 2010, Adamczyk et al. 2012).

The sub-coal complex is $20-80 \mathrm{~m}$ thick. It starts with the Paleogene deposits represented by debris patches of Mesozoic rocks of a thickness up to $37 \mathrm{~m}$. They fill depressions in the Mesozoic top, which was varied morphologically by both karstic and tectonic processes. The second element of this complex are the Neogene sandy sediments with an evident unconformity defined by the erosional base (Peryt \& Piwocki red. 2004).

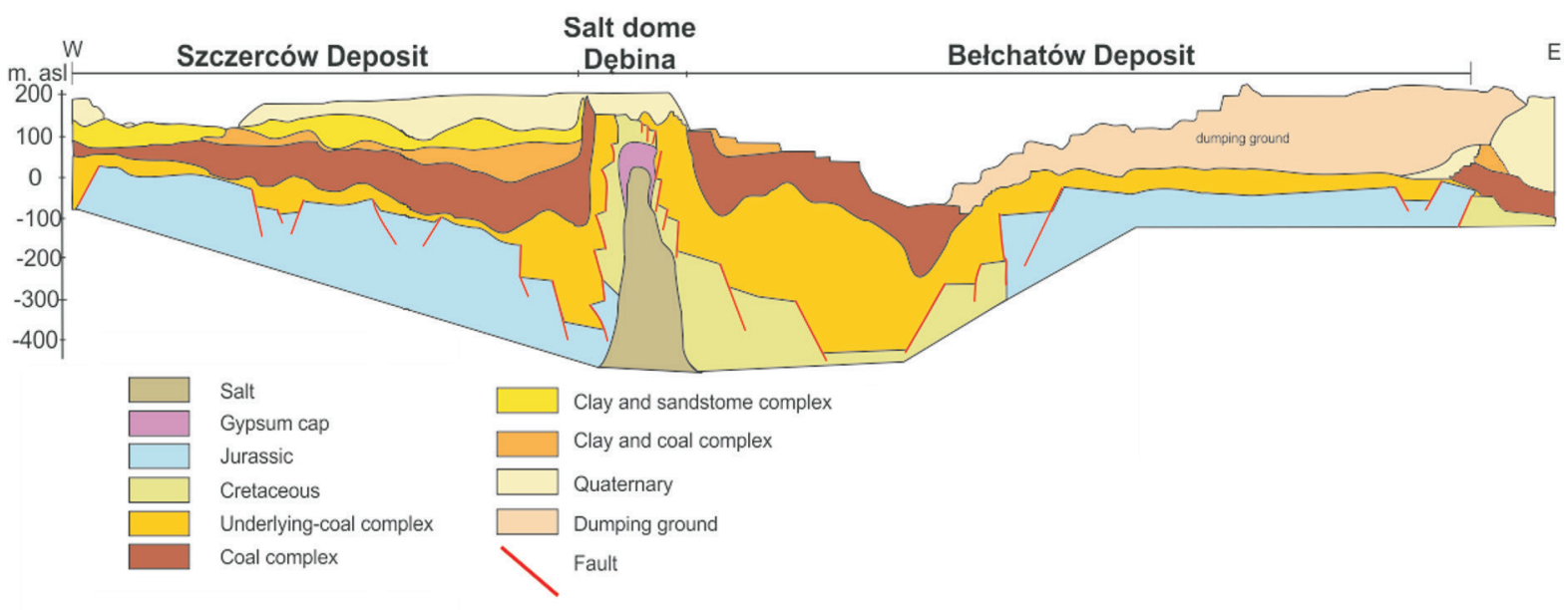

Fig. 2. Cross-section through the the Szczerców lignite deposit 
Moreover, they include two lenses of lignite with a thickness of up to $40 \mathrm{~cm}$. By on analogy to the Bełchatów deposit it is considered that these lignites are equivalents of the 4th Dabrowa lignite seam, DLS-4, from the Wielkopolska territory (Fig. 3) (Widera 2016). The total thickness of the sandy sediments with lignite lenses reaches $20 \mathrm{~m}$. At the top of the sub-coal complex lie medium-grained sands, interbedded by gravels. Additionally, in the western part of the Szczerców deposit a lacustrine chalk is present, while in the eastern and central parts of the deposit, coarse-grained sands with green clays are occurring. The thickness of these deposits ranges from 25 to $30 \mathrm{~m}$ (Wagner 2001).

The coal complex which is the main part of the Szczerców deposit, is divided into the main lignite seam and minor seams associated with a different carbonaceous coefficient. The minor seams form the lower part of the succession and this is represented by coarse-grained carbonaceous sands and thin lignite seams. It is characteristic of the western part of the deposit, where lacustrine deposits also occur. Moreover, there are few lignite seams with a thickness of up to $4 \mathrm{~m}$, which are divided into 4 seams in the east. These seams are composed of xylodetritic and detritic lignites. It is considered that they are an equivalent of the $3^{\text {rd }}$ Scinawa lignite seam (SLS-3). The thickness of the complex is from $30 \mathrm{~m}$ to $40 \mathrm{~m}$ (Leśniak et al. 2002). The main lignite seam thickness varies from $30 \mathrm{~m}$ to $90 \mathrm{~m}$, averaging $45 \mathrm{~m}$. It decreases gradually to the east, forming a syncline, which thickness increasing as a result of halokinesis. The main lignite seam is situated almost vertically in the vicinity of the Dębina Salt Dome (Fig. 2). It consists mainly of detritic and xylodetritic lignite with content of xylites $-20 \%$. A few interbeddings of paratonsteins are present within the main seam as the common element of the lacustrine environment (Wagner 2001). It is assumed that the bottom layers of the main lignite seam belong to the $3^{\text {rd }}$ Ścinawa lignite seam (ŚLS-3) of Early Miocene age (Fig. 3) (Widera 2016), while the layers close to the seam roof $(\sim 20 \mathrm{~m})$ are referred to the $2^{\text {nd }}$ Lusatian lignite seam (LLS-2) of Middle Miocene age (Wagner 2001).

The clay-coal and a clay-sandstrone complexes in the Szczerców deposit area were distinguished on the basis of similarity to the lithostratigraphic profile from the Bełchatów deposit, specifically the level of fossil tree trunks and the level of gravel pavement (Fig. 2). They are mainly composed of greenish sands and clays. Moreover, they are interbedded by carbonaceous sediments with thin lignite layers known as the 0 Poznań lignite seam of Late Miocene age (Fig. 3) (Widera 2016). The above-described Neogene sediments are capped by the Pleistocene continuous glaciogenic cover and the Holocene deposits with a total thickness from several to over $100 \mathrm{~m}$ (Fig. 2) (Wagner 2001).

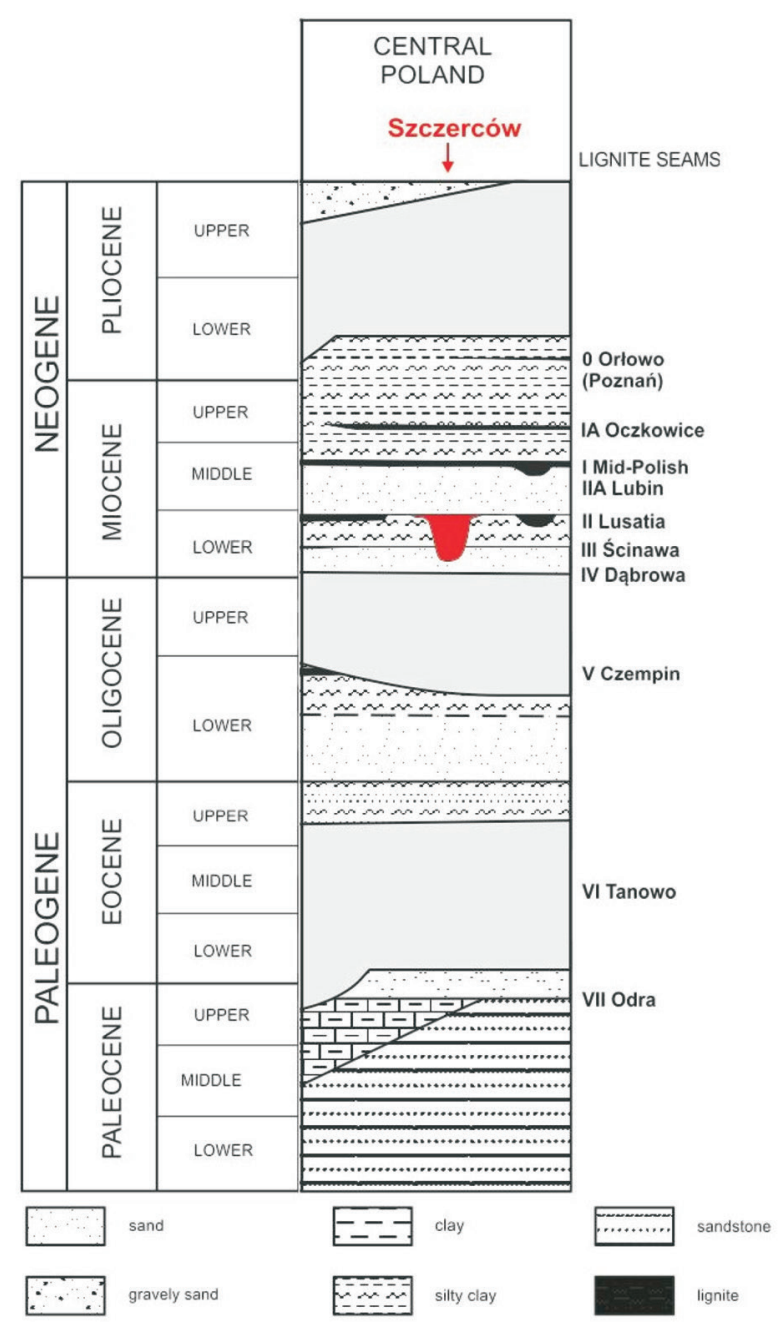

Fig. 3. Lithostratigraphic profile of the Szczerców lignite deposit (acc. to Czarnecki et al. 1992, Kasiński et al. 2010, modified)

\section{MATERIALS AND RESEARCH}

The study was based on data from 194 samples and they were obtained from 177 full-logging boreholes drilled in the Szczerców lignite deposits area (Fig. 4). The data were supplemented with 
drilling's profiles from the Geological Database of the Bełchatów Lignite Mine.

The main economic parameters of the Szczerców lignite deposit were subsequently examined. These were: depth of the coal complex top, depth of the coal complex base, thickness of the coal complex, thickness of the overburden, thickness of the balance lignite seam, carbonaceous coefficient, and the number of lignite seams in order to illustrate the geological structure. Additionally, some technical analysis of lignite from the Szczerców deposit were made based on: moisture content $\left(M^{a}\right)$, ash content $(A d)$, net calorific value (NCV) and total sulphur content $\left(S_{t}^{d}\right)$. The next step of the research was a statistical analysis of these parameters, including the arithmetic mean, minimum and maximum value, modal group, standard deviation, and the degree of variability of the classification based on the value of coefficients of variation. In addition, a quantitative analysis of the huminite group was performed and a random reflectance measured $\left(R_{0}\right)$. Based on the obtained results, contour maps of the distribution of economic parameters and quality assessment were created in the Surfer software using the weighted average method. It was mainly focused on the variability of these parameters in the Szczerców lignite deposit.
Finally, based on a statistical description, the examined lignite was classified according to the International Classification of In-Seam Coals and Low Rank Coal Utilization $(1998,2002)$.

\section{ECONOMIC PARAMETERES}

\section{The depth of the coal complex top}

The top of the coal complex was determined based on the depth of the shallowest lignite seam. It occurs on average on $53 \mathrm{~m}$ a.s.l. The top of the coal complex lies at the depth of $60 \mathrm{~m}$ a.s.l. in the majority of the Szczerców lignite deposit area (Fig. 5). Its maximum depth, of $93.4 \mathrm{~m}$ b.s.l., is located at the south-eastern boundary of the Kleszczów trough. Conversely, the coal complex lies in the highest position that is $193.6 \mathrm{~m}$ a.s.l., in the eastern part of the study area adjacent to the Dębina Salt Dome (Fig. 5).

\section{The depth of the coal complex base}

The average depth of the base of the coal complex is $7.35 \mathrm{~m}$ b.s.l. It was determined based on the bottom of the lowest lignite seam. The coal complex base lies the deepest in the south-eastern part of the Szczerców deposit, where it reaches up to $166.4 \mathrm{~m}$ b.s.l. (Fig. 6).
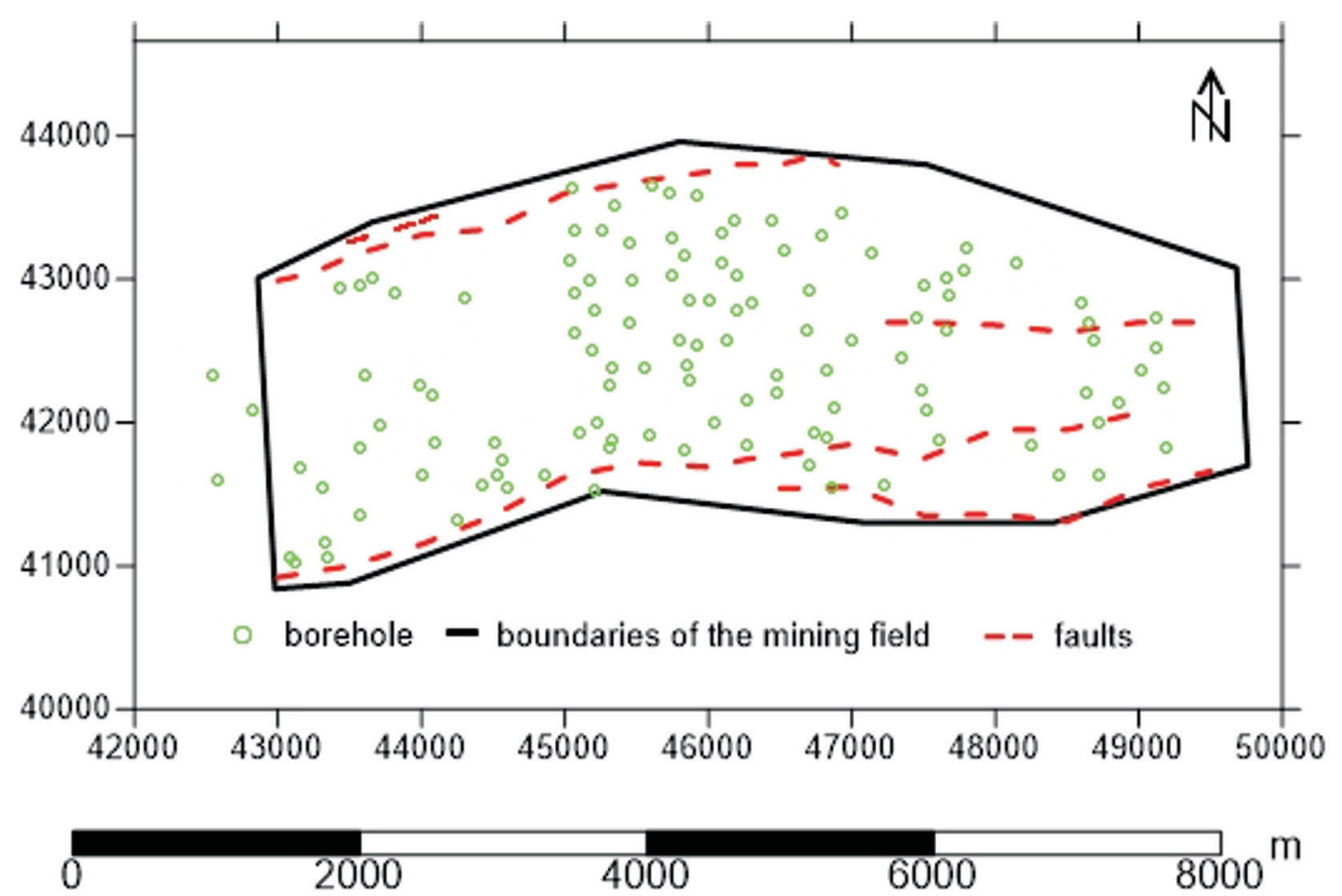

Fig. 4. Location of boreholes within the field of mining 


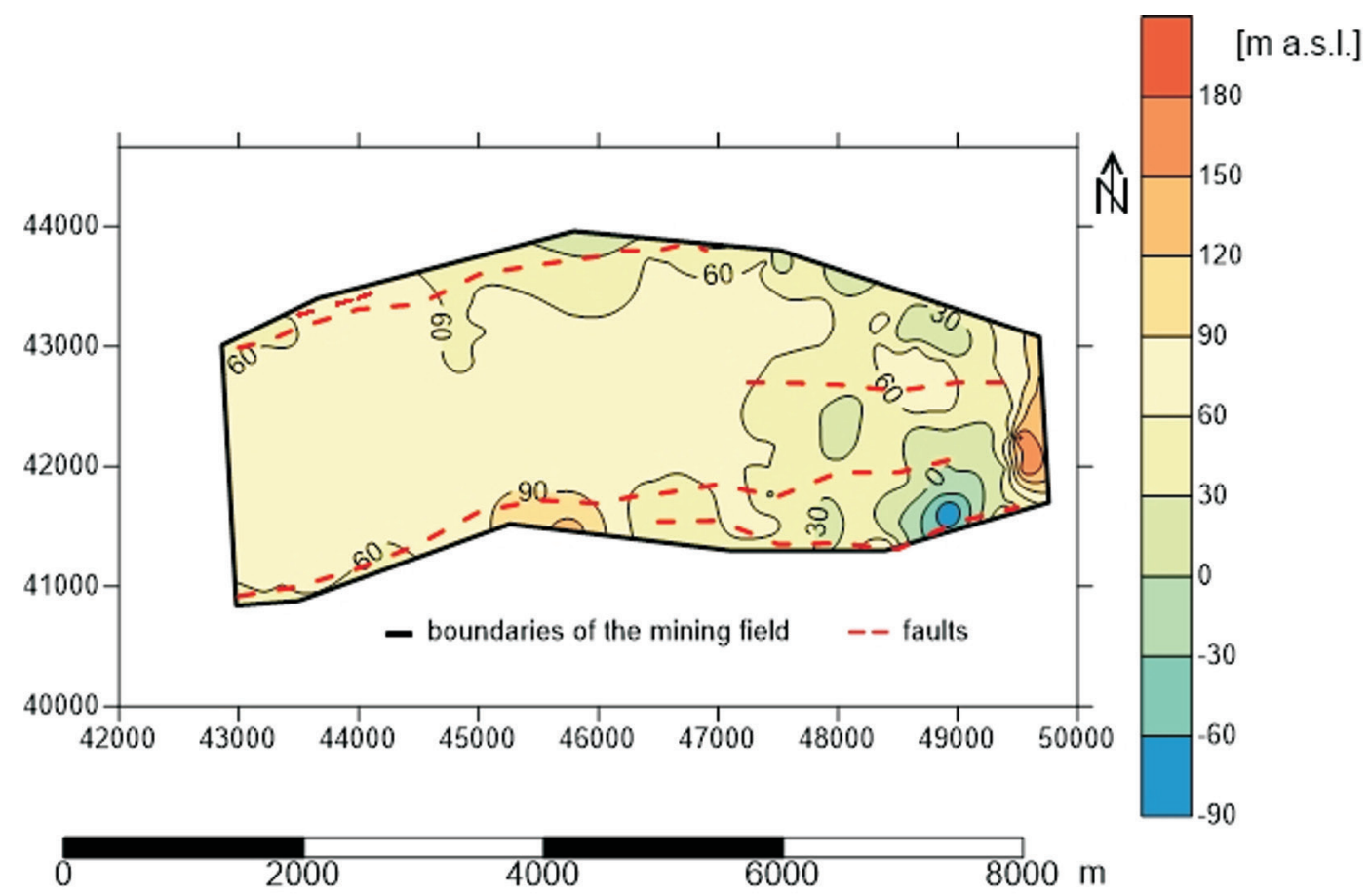

Fig. 5. Contour depth map of the top of the coal complex

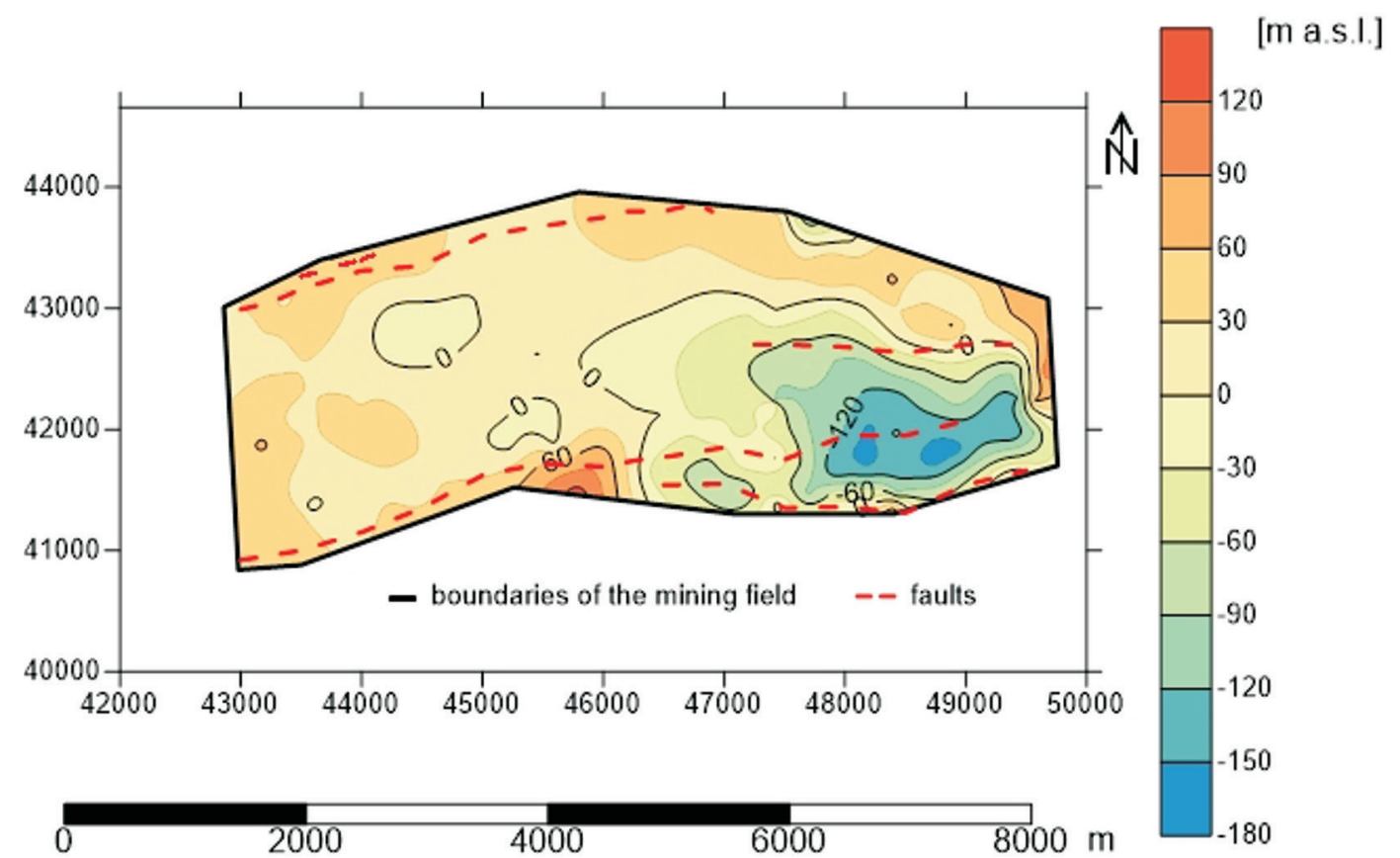

Fig. 6. Contour depth map of the base of the coal complex

The shallowest presence of lignite, belonging to the coal complex, was found at the depth of $145.1 \mathrm{~m}$ a.s.l. in the middle part of the southern border of the mining field. In the central territory of the Szczerców lignite deposit, the base of the characterized complex is at $20 \mathrm{~m}$ b.s.l. to $40 \mathrm{~m}$ a.s.l. (Fig. 6).

\section{The thickness of the coal complex}

The thickness of the coal complex is defined as a distance between the bottom of the lowest and the roof of the uppermost seams with a balance lignite thickness bigger than $3 \mathrm{~m}$. The coal complex is characterized by highly diversified 
thickness, averaging $52.44 \mathrm{~m}$ in the Szczerców deposit. Generally, in the western and central part of the deposit the thickness of coal complex is on average $50 \mathrm{~m}$. Only locally does the thickness reach $100 \mathrm{~m}$. The thickest part of the complex is in the south-eastern part of the study area, reaching up to $180 \mathrm{~m}$; however, at the eastern boundary of the Szczerców deposit it is about $260 \mathrm{~m}$. (Fig. 7). Such a great thickness variations are associated with halokinetic bending of the deposits, including the lignite seams, in the area adjacent to the Dębina Salt Dome. Therefore, the eastern part of the Szczerców lignite, where the coal complex shows the highest average thickness (100-125 m), may be considered as the most valuable for mining (Fig. 7).

\section{The thickness of the overburden}

A compact overburden consisting of Neogene (clay-coal and clay-sandstone complexes) and Pleistocene sediments with an average thickness of $96.9 \mathrm{~m}$ can be found above the coal complex (Fig. 8). This thickness is typical of the central and western parts of the mining field. The highest thickness of the overburden, of up to $267.7 \mathrm{~m}$, can be found in the south-eastern part of the Szczerców field. The overburden thickness decreases towards east in the direction of the Dębina
Salt Dome. Above this halotectonic structure the overburden thickness reaches the minimum value, which is close to $0 \mathrm{~m}$ (Fig. 8).

\section{The overburden ratio}

The overburden ratio is expressed as a linear relationship between the thickness of the overburden and the thickness of the coal complex measured in all boreholes.

The obtained data were used to generate a map to show the variation of the overburden ratio. The values above 30:1 were not taken into account for the map construction, as they were sporadic and associated with a low thickness of coal complex at the boundaries of the mining field. The maximum value of the overburden ratio is more than $120: 1$, while its minimum value is 0 . In the latter case, it indicates a lack of the overburden in a single borehole. However, the overburden ratio of 3:1 is the most characteristic for the major part of the Szczerców lignite deposit (Fig. 9).

\section{Total thickness of the balance lignite seams}

The thickness of the lignite has been determined as the sum of the thickness of the lignite seams. Their maximum thickness is present in the south-eastern part of the Szczerców lignite deposit; it is up to $177.5 \mathrm{~m}$ (Fig. 10).

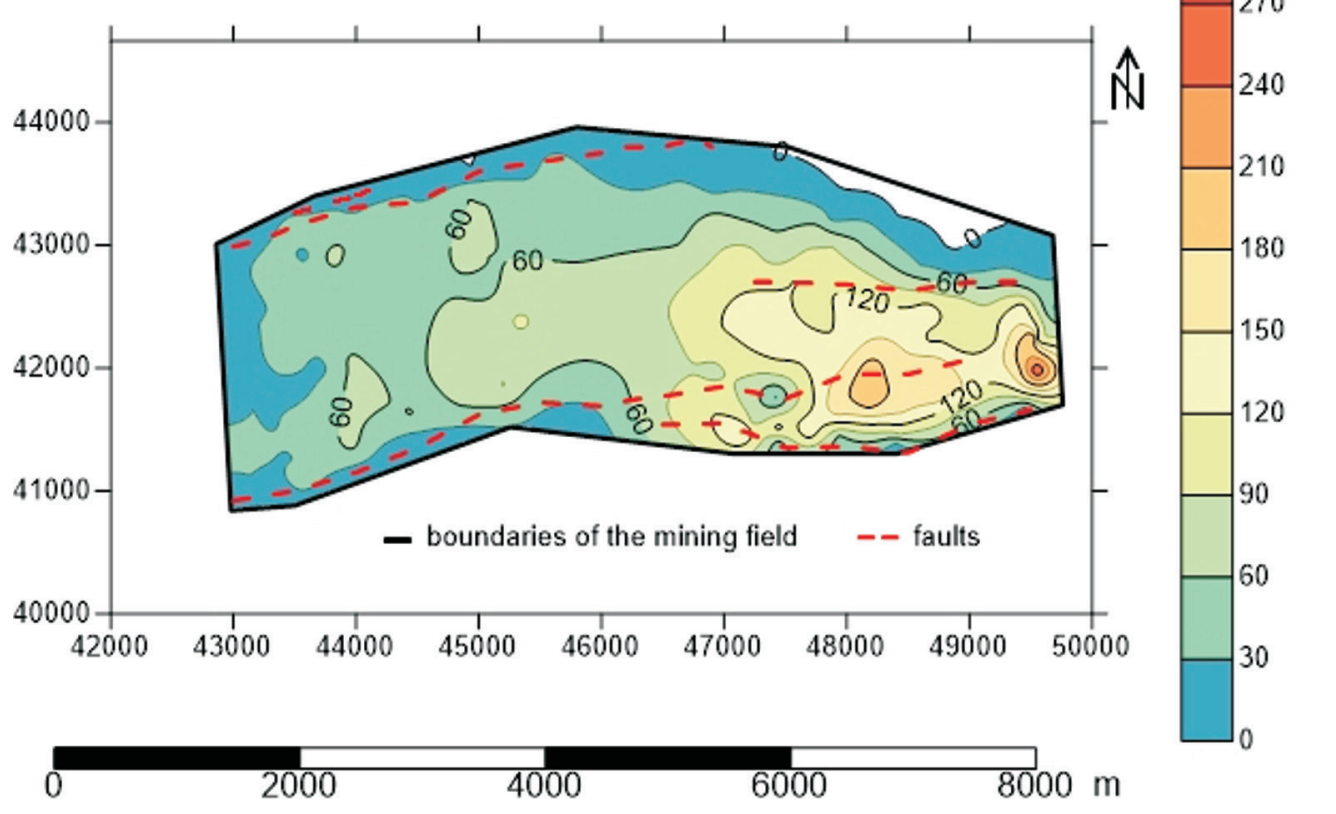

Fig. 7. Thickness contour map of the coal complex 


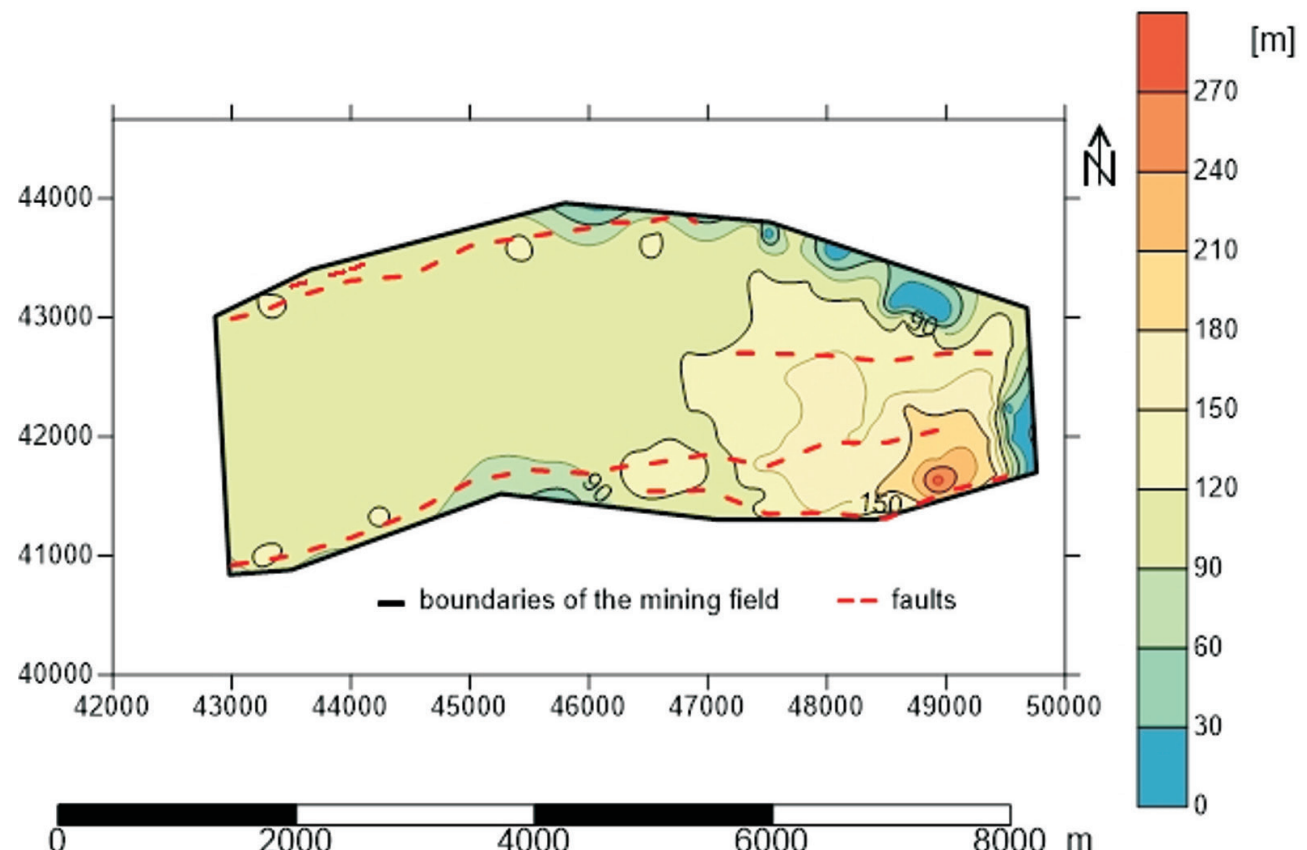

Fig. 8. Contour map of the thickness of overburden

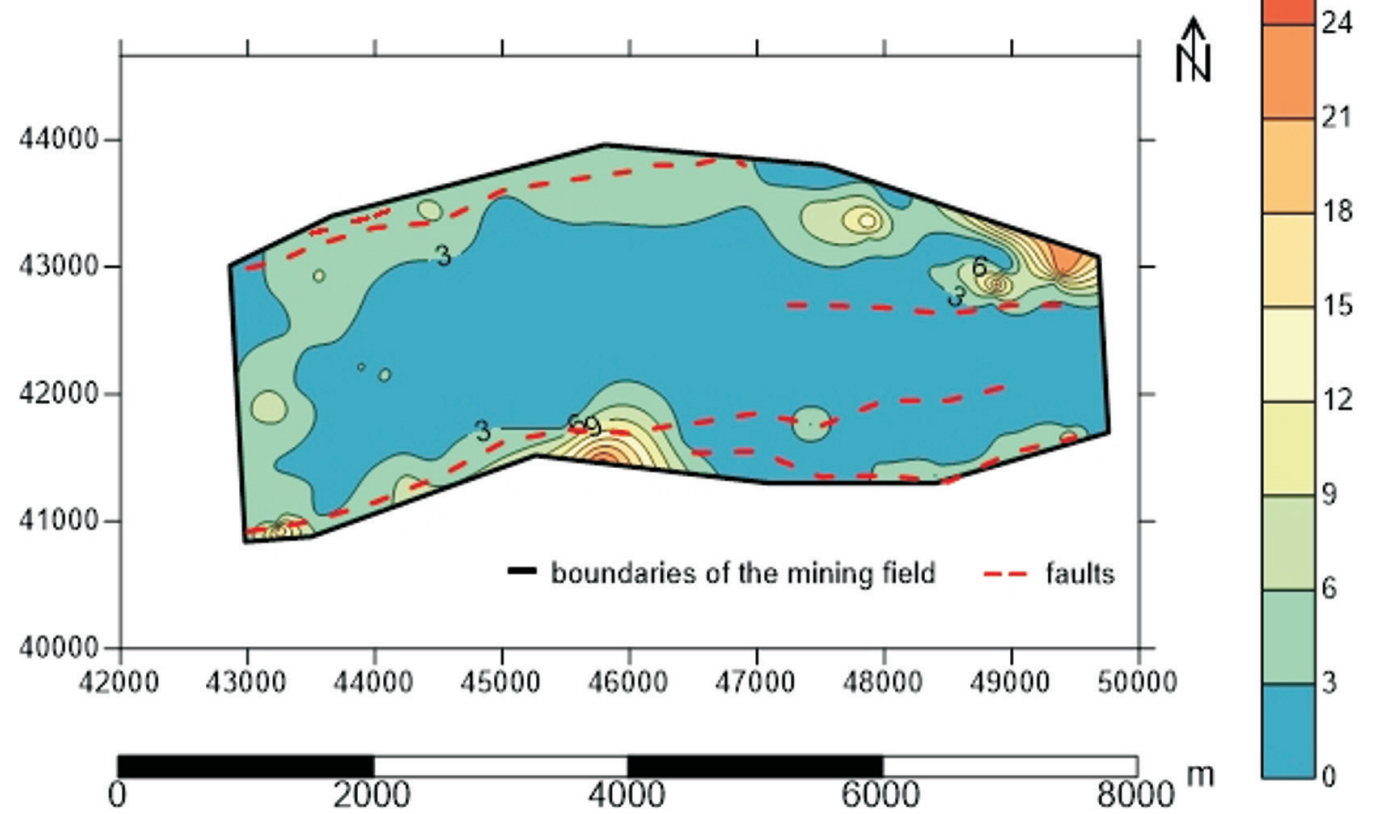

Fig. 9. Contour map of the overburden ratio

This value is the apparent thickness resulting from measuring the lignite thickness along the axis of the drilling. For instance, there is no evidence of the lignite thickness in the most northwestern part of the studied area. In the western part of the mining field the lignite thickness is about $60 \mathrm{~m}$ and gradually decreases towards the west, while in its south-eastern part the lignite thickness expressly exceeds $80 \mathrm{~m}$ (Fig. 10). The average thickness of the lignite seams for the entire Szczerców deposit is about $45 \mathrm{~m}$.

\section{Structure of the coal complex}

The structure of the coal complex was analyzed on the basis of the amount of the balance lignite seams. 


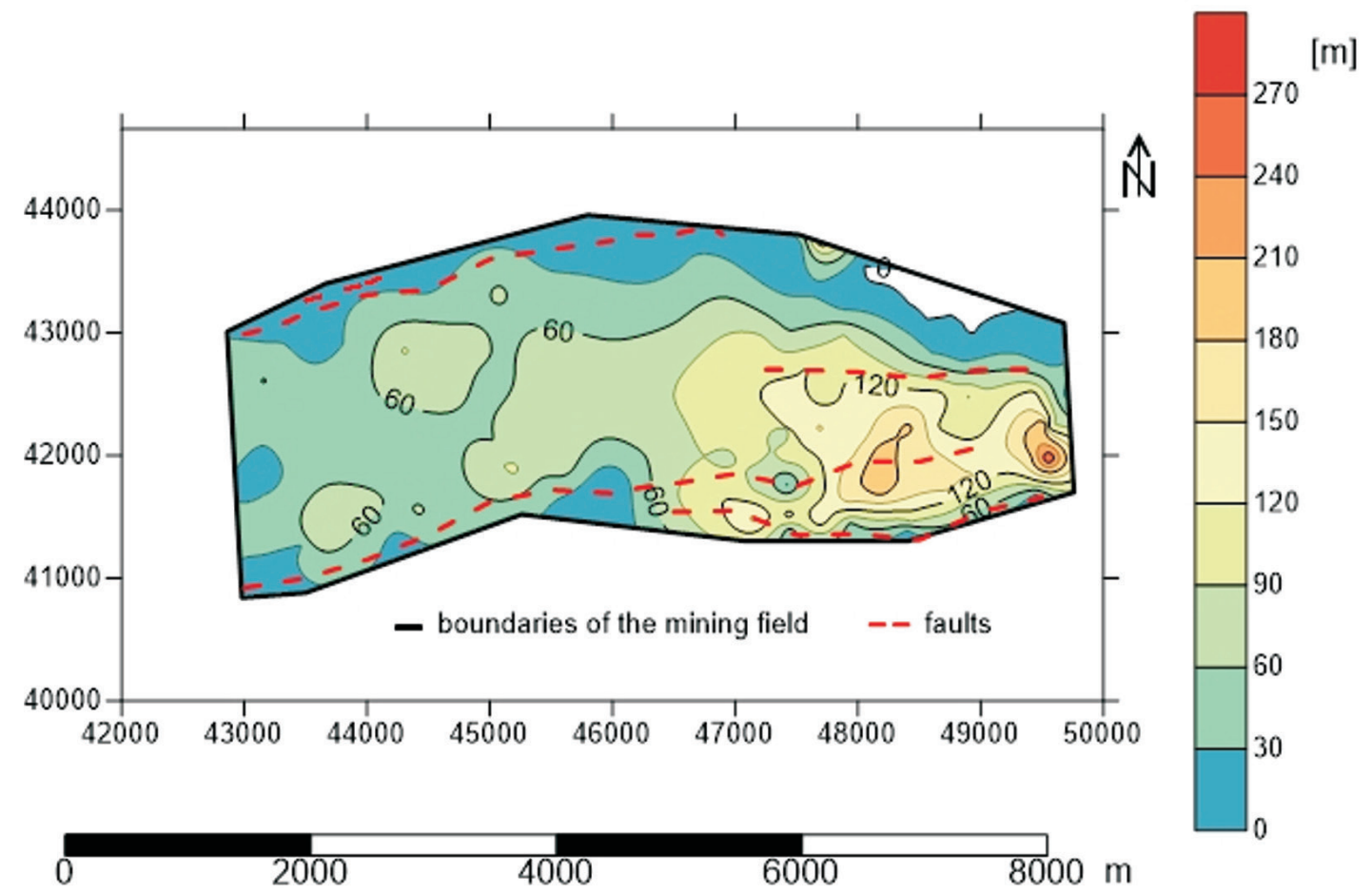

Fig. 10. Contour map of the total thickness of balance lignite

One seam is characteristic of the southern and northern parts of the Szczerców deposit (Fig. 11). Gradually, the number of seams increases towards the southern edge of the field, namely 14 seams are present in the south-western part of the examined area (Kozioł \& Sośniak 2011). This confirms the hypothesis about the synsedimentary evolution of the Kleszczów trough (e.g. Gotowała \& Hałuszczak 2002, Widera \& Hałuszczak 2011). On the other hand, in the central part of the Szczerców deposit the coal complex consists of 2-4 lignite seams (Fig. 11).

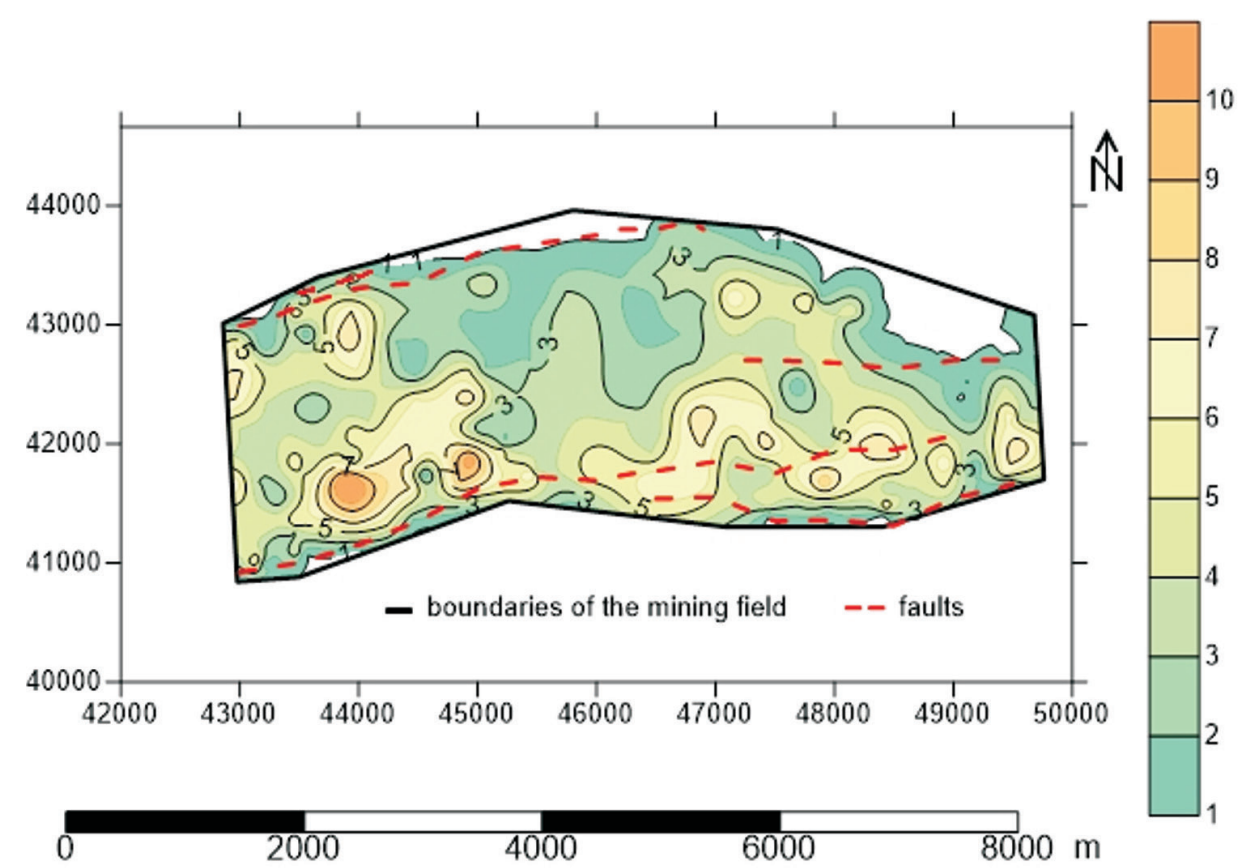

Fig. 11. Contour map of the amount of coal seams 


\section{The carbonaceous coefficient}

The carbonaceous coefficient is one of the most important parameters determining the value of the lignite deposit. The minimum values are associated with the proximity of tectonic zones, active during the peat accumulation in the Miocene, occurring in the north-western part and along the southern boundary of the mining field. In these areas, the carbonaceous coefficient decreases rapidly to less than 30\%. On average, in the Szczerców lignite deposit the carbonaceous coefficient is higher than $75 \%$. In the central and eastern parts of the examined deposit it locally amounts to $100 \%$ (Fig. 12). However, the average carbonaceous coefficient is $58 \%$ for the entire Szczerców lignite deposit.

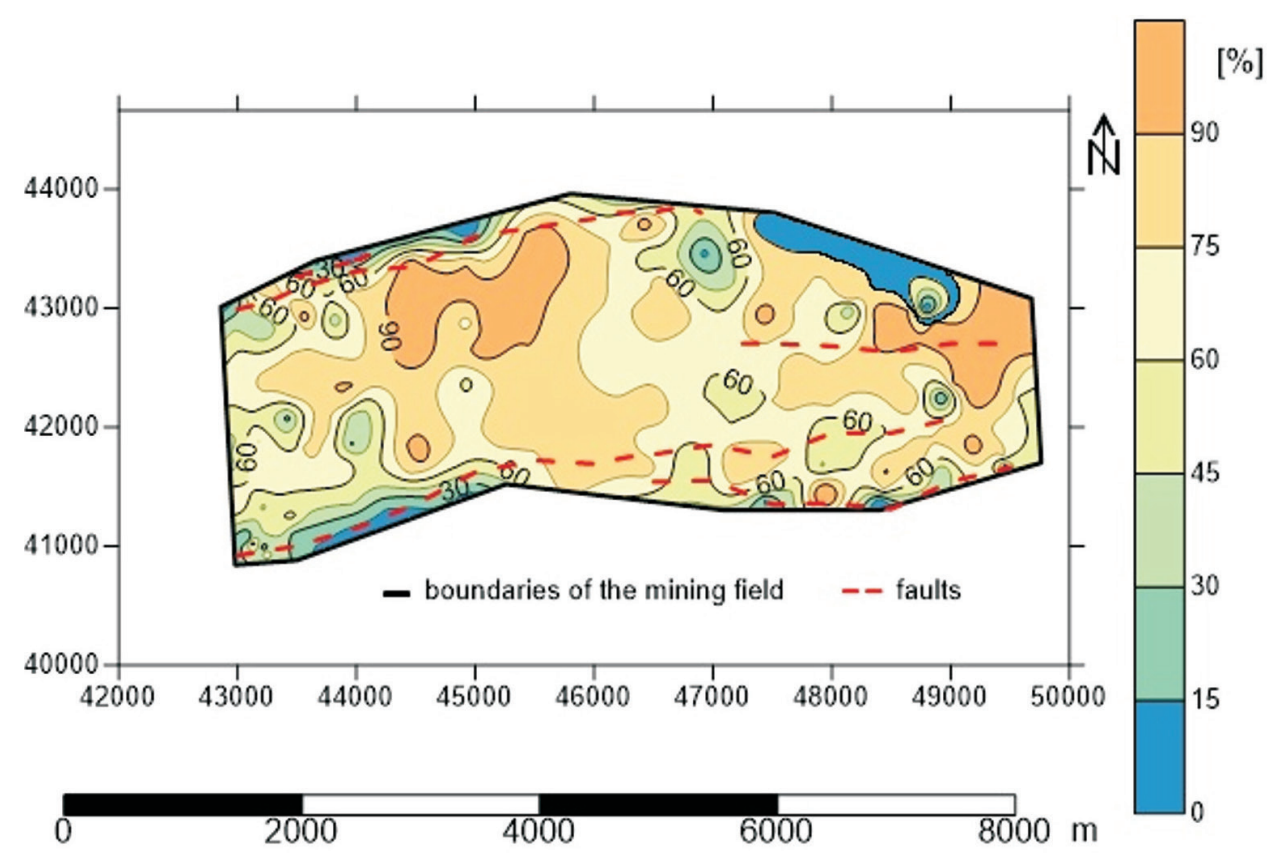

Fig. 12. Contour map of carbonaceous coefficient

\section{QUALITY ASSESSMENT}

\section{Natural moisture $\left(M^{a r}\right)$}

Total moisture is the humidity of freshly mined lignite present in dewatered deposits, and calculated as a percentage of the water weight in the lignite. The natural moisture of lignite changes in the range $38-58 \%$ by weight in the Szczerców deposit area (Tab. 1). The lowest values can be probably explained by the presence of faults or fissures in the analyzed sample, as humidity of about $40 \%$ or less by weight is typical for subbituminous coal. The moistest lignite can be found locally in the central and north-eastern parts of the Szczerców deposit. The areas with the lowest moisture content are located in the south-eastern studied territory, where open faults or brecciated lignites have been documented. This phenomenon contributes to the dewatering of lignite. In summary, in the majority of the Szczerców deposit the natural lignite moisture varies from 48 to $54 \%$ by weight (Fig. 13).

\section{Ash content $\left(A^{d}\right)$}

The ash is a solid residue left after the burning of carbonaceous rocks, including lignite. In accordance with accepted standards in Poland, the ash content of $40.0 \%$ by weight, calculated on a dry basis, is recognized as an upper limit allowing the use of coal for electricity purposes (Bartuś 2003). The ash content of $22.0 \%$ by weight is typical for the central area of the Szczerców deposit. The lowest ash content, about $17.3 \%$ (Tab. 1), was found in the eastern part, while the highest values of $36.6 \%$ were obtained from the south-western territory of the Szczerców lignite deposit (Fig. 14). These high ash values can be explained by the presence of a vast alluvial fan, resulting in a very high reduction of the lignite quality. 
Table 1

Statistical analysis of the quality parameters of the Szczerców deposit liginite

\begin{tabular}{|l|c|c|c|c|c|c|c|}
\hline \multicolumn{1}{|c|}{$\begin{array}{c}\text { Quality } \\
\text { parameters }\end{array}$} & $\begin{array}{c}\text { Arithmetic } \\
\text { mean }\end{array}$ & $\begin{array}{c}\text { Minimum } \\
\text { value }\end{array}$ & $\begin{array}{c}\text { Maximum } \\
\text { value }\end{array}$ & $\begin{array}{c}\text { Modal } \\
\text { group }\end{array}$ & $\begin{array}{c}\text { Standard } \\
\text { deviation }\end{array}$ & $\begin{array}{c}\text { Degree of } \\
\text { variability }\end{array}$ & $\begin{array}{c}\text { Variability } \\
\text { Group } \\
\text { (Antropov et al. } \\
\text { red. 1960) }\end{array}$ \\
\hline $\begin{array}{l}\text { Natural } \\
\text { moisture }\left(M^{a}\right)\end{array}$ & $51.7 \%$ & $38.7 \%$ & $57.7 \%$ & $50-53 \%$ & 3.5 & $6.80 \%$ & very week \\
\hline Ash content $\left(A^{d}\right)$ & $23.6 \%$ & $17.3 \%$ & $36.6 \%$ & $20-24 \%$ & 4.23 & $8.01 \%$ & very week \\
\hline $\begin{array}{l}\text { Net calorific } \\
\text { value }(\mathrm{NCV})\end{array}$ & 7.331 & $\begin{array}{c}5.564 \\
\mathrm{MJ} / \mathrm{kg}\end{array}$ & $\begin{array}{c}11.072 \\
\mathrm{MJ} / \mathrm{kg}\end{array}$ & $\begin{array}{c}7.950-8.370 \\
\mathrm{MJ} / \mathrm{kg}\end{array}$ & 543.72 & $31.06 \%$ & week \\
\hline $\begin{array}{l}\text { Total sulphur } \\
\text { content }\left(S_{t}^{d}\right)\end{array}$ & $3.36 \%$ & $2.41 \%$ & $4.23 \%$ & $3.01-3.5 \%$ & 0.46 & $13.69 \%$ & very week \\
\hline
\end{tabular}

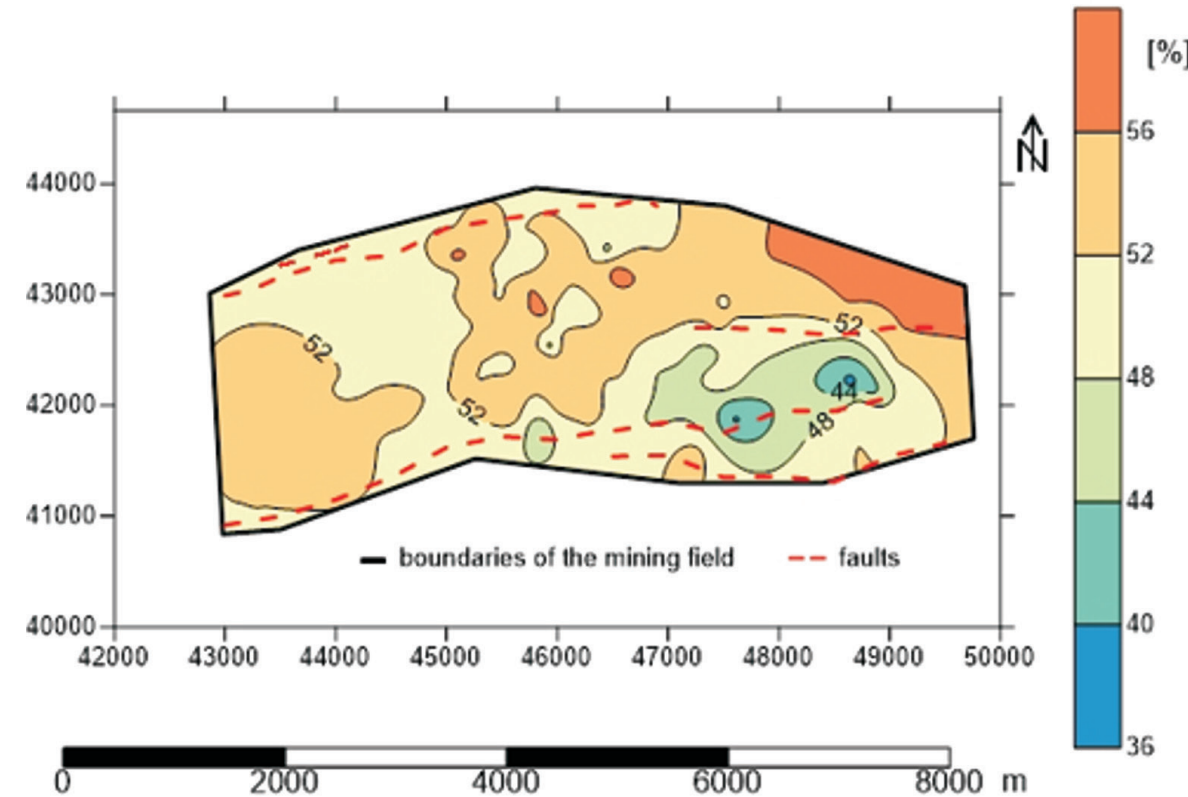

Fig. 13. Contour map of natural moisture

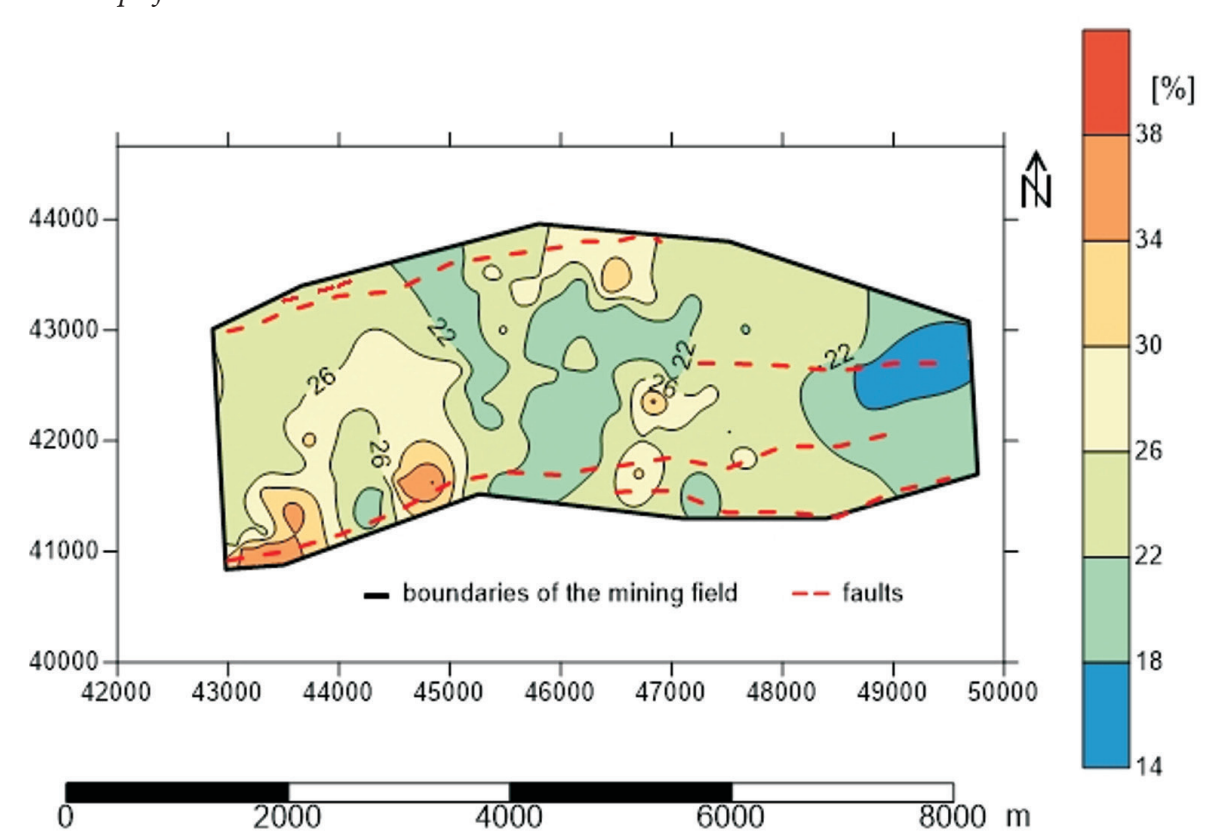

Fig. 14. Contour map of the ash content (dry basis) 


\section{Net calorific value (NCV)}

Net calorific value is the best indicator of the fuel's usefulness for energy purposes. The net calorific value varies significantly for lignites from the Szczerców deposit (Fig. 15, Tab. 1). The lowest values $(5.564 \mathrm{MJ} / \mathrm{kg})$ occur in the north-western zone of the mining field. In its western part, due to the presence of the alluvial fan, the net calorific value is less than $6.690 \mathrm{MJ} / \mathrm{kg}$. The central part of the Szczerców deposit is characterized by an average net calorific value of $8.370 \mathrm{MJ} / \mathrm{kg}$. Lignites with a maximum net calorific value, up to $11.072 \mathrm{MJ} / \mathrm{kg}$, are located in the south-western part of the study area. Compared to other parameters, the net calorific values shows the largest variability in the Szczerców deposit (Fig. 15, Tab. 1).

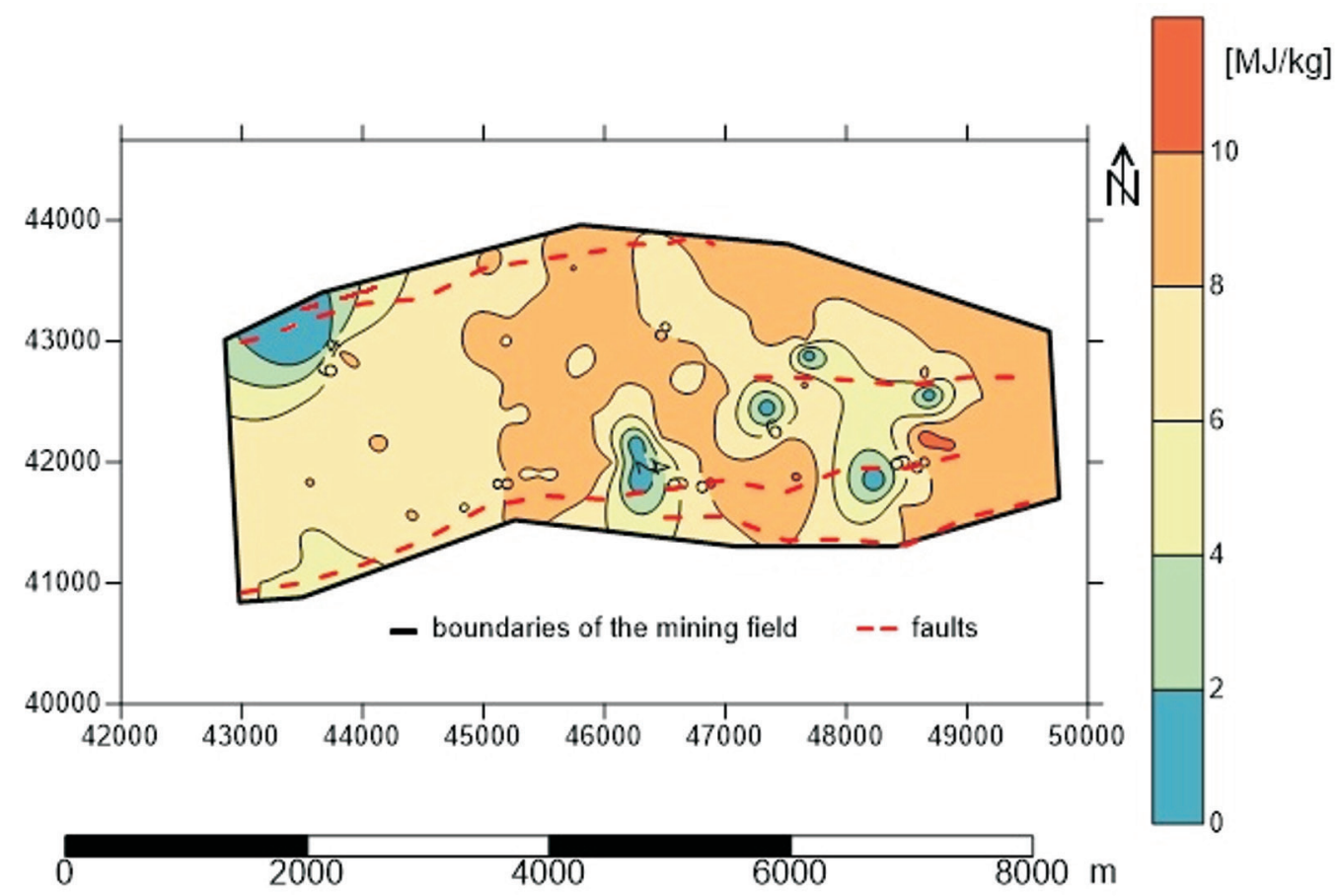

Fig. 15. Contour map of the net calorific value

\section{Total sulphur content $\left(S_{t}^{d}\right)$}

Sulphur in lignite is considered one of the main elements, which is very harmful for environment (Styrnol \& Wagner 2007). The results of the suphur content of lignite from the Szczerców deposit show that it is highly sulphated (Fig. 16, Tab. 1). All tests have shown values of sulphur content greater than $2 \%$ by weight (Styrnol \& Wagner 2007). However, the total sulphur content in Szczerców lignite deposit changes in the range $2.41-4.23 \%$ by weight (Tab. 1 ). Lignites with a high content of this parameter occur mainly in the northern and central parts of the deposit. The lignite with the lowest sulphur content covers the south-eastern part of the mining field, among others, parts adjacent to the Dębina Salt Dome (Fig. 16).

\section{Huminite group macerals}

Huminite group includes minerals derived from tissues of higher plants with a different degree of the coalification process. Some of macerals belonging to this group (e.g. atrinite, densinite, textinite) favor briquetting of coal without a binding component and coking coal in the briquettes (Kwiecińska \& Wagner 1997). The average content of the huminite group for the Szczerców deposit is $84.9 \%$ and varies in the range from 78 to $90 \%$ (Fig. 17). Its maximum was found in the south-western part of the deposit, where the lignite thickness decreases significantly. On the other hand, its minimum values occur in isolated areas in the central part of the mining field. In the western territory of the Szczerców lignite deposit the content of huminite group macerals reaches a value above $88.5 \%$ (Fig. 17). 


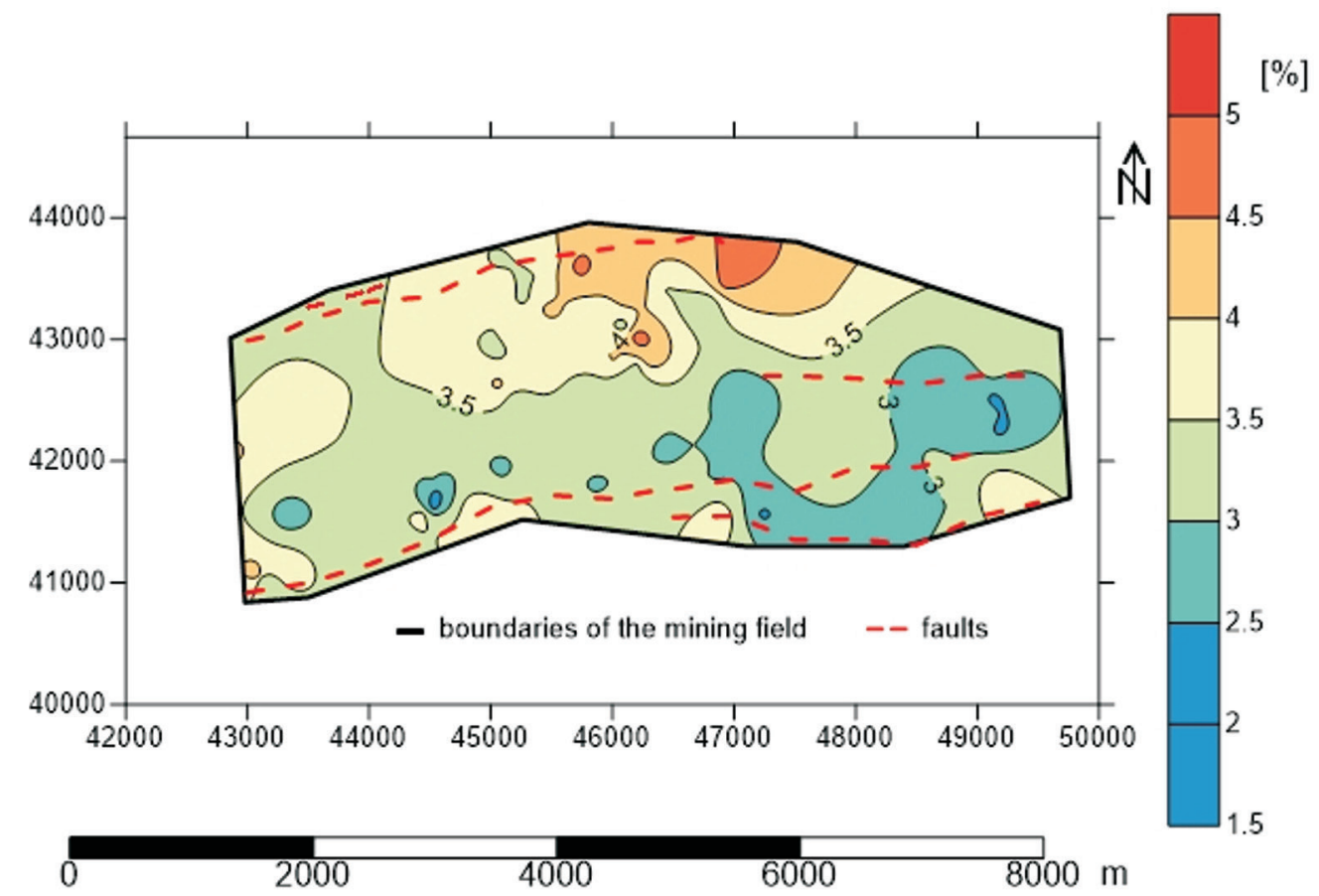

Fig. 16. Contour map of sulphur content (dry basis)

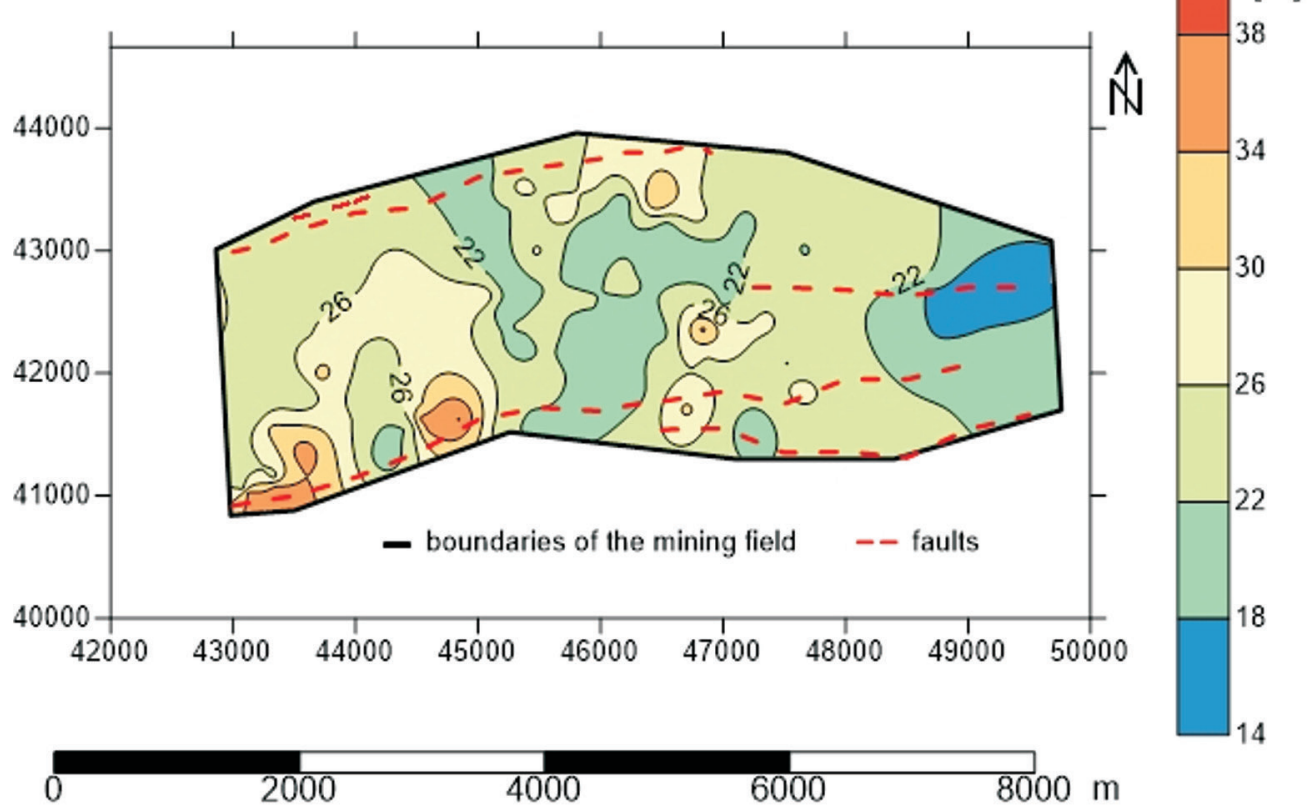

Fig. 17. Isopachous map of huminite group macerals content in lignite from the Szczerców deposit

\section{Random reflectance $\left(R_{0}\right)$}

Random reflectance is used to determine the coalification degree. The random reflectance value in the Szczerców lignite deposit ranges from $0.24 \%$ to $0.30 \%$, averaging $0.27 \%$. The highest values were found in the eastern part of the deposit in the vicinity of the Dębina Salt Dome, while the minimum values occur in small patches in the north-western part of the mining field (Fig. 18). Such a high value of the random reflectance near the dome helps to distinguish the salt 
structure surrounding the rest of the area of the Szczerców lignite deposit. This is due to the thermogenic effects of the Dębina Salt Dome on the lignite properties. Generally, there is a clear trend of increasing the random reflectance values from the west to the east (Fig. 18).

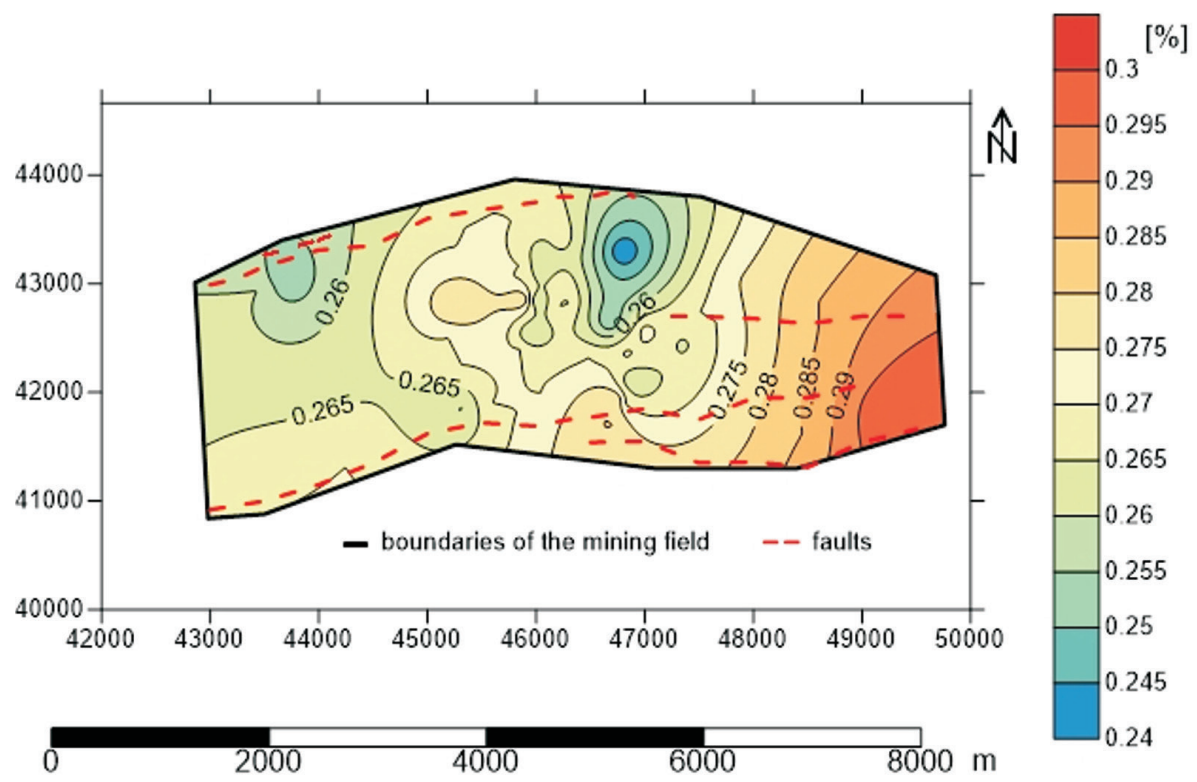

Fig. 18. Contour map of huminite group macerals content in lignite from the Szczerców deposit

\section{International classification of lignite from the Szczerców deposit}

In accordance with the principles of the standard International Classification of In-Seam Coals (1998) and its supplement the Low Rank Coal Utilization - International Codification System (2002) lignite from the Szczerców deposit is humic orto-lignite (Bielowicz 2012a, 2012b). According to the average values of the technological parameters of coal, the code for the studied lignite as follows: humic low-rank C (orto-lignite) 195123 33; where: C - low class, which is called the clean coal, 19 - net calorific value on dry ash free basis (here is $18.861 \mathrm{MJ} / \mathrm{kg}$ ), 51 - average natural moisture on received basis (here is 51.7\%), 23 - average ash content on a dry basis (here is $23.6 \%$ ), and 33 - average sulphur content on a dry basis (here is $3.36 \%$ ).

\section{DISCUSSION}

In Poland, lignite was extracted by 5 mines from 9 deposits in June 2016 (Fig. 1, Tab. 2) (Pietraszewski 2015, Szuflicki et al. 2015). For many years, the biggest of them has obviously been the Bełchatów Lignite Mine (Kozioł \& Sośniak 2011).

It is assumed that the electricity complex, including the Bełchatów, Szczerców opencasts and the Bełchatów power plant, will operate until 2038. If lignite mining from the Złoczew deposit is begun, the life of the aforementioned electricity complex will be extended until 2050 (e.g. Czarnecki et al. 2010, Pietraszewski 2015, Widera et al. 2016).

The Szczerców lignite deposit coal complex included the $2^{\text {nd }}$ Lusatian lignite seam (LLS-2) and the $3^{\text {rd }}$ Ścinawa lignite seam (ŚLS-3) (e.g. Widera 2016). Compared to other deposits in Poland, in which the same type of lignite seams are present, the lignite from the Szczerców deposit is characterized by weak technological parameters (Tab. 3). It contains high ash and sulphur content, and has a low net calorific value. Only natural moisture is one of the best values among comparable Polish lignites. All of these far from ideal parameters are compensated for by the very large thickness of the seams in the Szczerców lignite deposit (Tab. 3).

First of all, the most important are similarities of the lignite quality parameters between the neighboring Szczerców and Bełchatów deposits (Tab. 3). Mining of lignite from the Szczerców deposit will allow the extension of the operation of the Bełchatów power plant after the completion of lignite production from the Bełchatów deposit. 
Table 2

The parameters of selected lignite deposits (Bielowicz 2012a, supplemented)

\begin{tabular}{|l|l|c|c|c|c|c|}
\hline $\begin{array}{c}\text { Lignite } \\
\text { deposits }\end{array}$ & $\begin{array}{c}\text { Lignite seams } \\
(\text { Widera 2016) }\end{array}$ & $\begin{array}{c}\text { Average } \\
\text { thickness } \\
{[\mathbf{m}]}\end{array}$ & $\begin{array}{c}\text { Natural } \\
\text { moisture } \\
\left(\boldsymbol{W}_{t}^{r}\right)[\mathbf{w t} \%]\end{array}$ & $\begin{array}{c}\text { Ash content } \\
\left(\boldsymbol{A}^{\boldsymbol{d}}\right)[\mathbf{w t} \mathbf{m}]\end{array}$ & $\begin{array}{c}\text { Net calorific } \\
\text { value }(\mathbf{N C V}) \\
{[\mathbf{M J} / \mathbf{k g}]}\end{array}$ & $\begin{array}{c}\text { Total sulphur } \\
\text { content }\left(\boldsymbol{S}_{t}^{\boldsymbol{d}}\right) \\
{[\mathbf{w t} \%]}\end{array}$ \\
\hline Szczerców & LLS-2+ŚLS-3 & 45 & 51.7 & 23.6 & 7.331 & 3.36 \\
\hline Bełchatów & LLS-2+ ŚLS-3 & 55 & 53.5 & 19.1 & 7.879 & 1.89 \\
\hline Sieniawa & LLS-2 & 18 & 55.0 & 10.8 & 8.501 & 0.99 \\
\hline Adamów & MPLS-1 & 6 & 51.3 & 8.6 & 9.668 & 0.31 \\
\hline Lubstów & $\begin{array}{l}\text { MPLS-1 } \\
\text { +LLS-2 }\end{array}$ & 15 & 50.5 & 11.0 & 10.354 & 1.27 \\
\hline Turów & LLS-2+ ŚLS-3 & 31 & 52.0 & 8.0 & 10.888 & 0.44 \\
\hline
\end{tabular}

MPLS-1 $1^{\text {st }}-$ Mid-Polish lignite seam, Middle Miocene; LLS-2 $2^{\text {nd }}-$ Lusatian lignite seam, Middle Miocene; ŚLS-3 $3^{\text {rd }}-$ Ścinawa lignite seam, Lower Miocene.

Table 3

Lignite mining in 2014 in Poland (Szuflicki et al., 2015; supplemented).

\begin{tabular}{|l|c|c|}
\hline $\begin{array}{c}\text { Deposit } \\
\text { name }\end{array}$ & $\begin{array}{c}\text { Output [million } \\
\text { tones] }\end{array}$ & $\begin{array}{c}\text { Participation } \\
\text { in the national } \\
\text { mining [\%] }\end{array}$ \\
\hline Bełchatów & 26.637 & 41.62 \\
\hline Szczerców & 15.756 & 24.63 \\
\hline Turów & 7.728 & 12.07 \\
\hline Pątnów IV & 5.351 & 8.36 \\
\hline Adamów & 3.220 & 5.03 \\
\hline Tomisławice & 2.122 & 3.32 \\
\hline Drzewce & 1.885 & 2.94 \\
\hline Koźmin & 1.196 & 1.86 \\
\hline Sieniawa I & 0.107 & 0.17 \\
\hline Sum: & 64.002 & 100 \\
\hline
\end{tabular}

The south-eastern parts of the Szczerców lignite deposit are characterized by the best economic parameters and high quality. This area has the largest thickness of the coal complex, including the balanced lignite seams. There, the top and base of the coal complex lie deeper than in other parts of the deposit. However, it does not mark on the variation map of the overburden ratio, because the bigger thickness of lignite is compensated for by the increased thickness of overburden. The net calorific value is also typically $30 \%$ higher in the south-eastern part of the field compared to the entire Szczerców lignite deposit. Moreover, the smallest content of ash (approx. 15\% lower) and sulphur content (approx. 1\% lower) have been found in the same area. Therefore, the south-eastern part of the studied area is called the 'Power Point' due to being the most economically valuable part of Szczerców lignite deposit.

Slightly less attractive for lignite mining is an eastern territory of the deposit, in the vicinity of the Dębina Salt Dome. The high-quality parameters determined there and along with the shallow depth of the lignite seam are very favorable. However, the proximity to the highly-elevated salt diapir means that the salt tectonic breccia is present within the lignite seam and the mine water is characterized by increased salinity. Therefore, the lignite exploitation will require modified and improved mining techniques. In order to reduce the negative impact of the Dębina Salt Dome on the mining operation the lignite from the aforementioned area is planned to be mined in the final stage of the Szczerców opencast existence.

\section{CONCLUSIONS}

The examined lignite from the Szczerców deposit is characterized by the best economic parameters and high quality in its south-eastern part. This area, called the "Power Point", is of particular importance for the Bełchatów mine. However, due to the proximity of the Dębina Salt Dome the mining activities might be difficult; therefore, they will be conducted at a later time in the vicinity of the salt structure.

In summary, the lignite from the Szczerców deposit is a good energy source for electricity production. It will extend the operation of the Bełchatów lignite-fired power station until 2038. This is due to the occurrence of favorable 
technological parameters in most parts of the deposit. On the other hand, the technological quality of lignite from the examined Szczerców deposit is similar to that from the Bełchatów deposit.

This work was created thanks to the provided data by the Betchatów Lignite Mine. The author would like to warmly thank the Reviewers and Editors of the Geology, Geophysics \& Environment for their careful reading of the manuscript and critical, but very helpful remarks, comments and advice.

\section{REFERENCES}

Adamczyk K., Jończyk M.W. \& Skórzak A., 2012. Kopaliny towarzyszące eksploatacji Złoża Węgla Brunatnego Bełchatów - historia dokumentowania i zagospodarowania. Kalendarium. Górnictwo Odkrywkowe, 53, 1-2, 25-41.

Antropov P.Ya., Prokof'yev A.P. \& Smirnov V.I. (red.), 1960. Podschet zapasov mestorozhdeniy poleznykh iskopayemykh. Gosudarstvennoye nauchno-tekhnicheskoye izdatel'stvoliteratury po geologii i okhrane nedr, Moskva [Антропов П.Я., Прокофьев А.П. \& Смирнов В.И. (ред.), 1960. Подсчет запасов месторождений полезных искоnаемых. Государственное научно-техническое издательство литературы по геологии и охране недр, Москва].

Bartuś T., 2003. Parametry chemiczno-technologiczne i oparte na nich klasyfikacje wegli brunatnych. Kraków, Statutory research no.: 11.11.140.808 [manuscript].

Bielowicz B., 2012a. A new technological classification of low-rank coal on the basis of Polish deposits. Fuel: the science and technology of fuel and energy, 96, 497-510.

Bielowicz B., 2012b. Schemat nowej technologicznej klasyfikacji krajowego węgla brunatnego w myśl zasad międzynarodowych. [in:] Jakubowski J. \& Wątroba J. (red.), Zastosowania metod statystycznych $w$ badaniach naukowych, 4, Wydawnictwo StatSoft Polska, Kraków, 373382.

Ciuk E., 1980. Tektonika rowu Kleszczowa i jej wpływ na warunki powstania złoża węgla brunatnego. [in:] Barczyk W. (red.), Przewodnik LII Zjazdu Polskiego Towarzystwo Geologicznego: Bełchatów, 11-14 września 1980, Wydawnictwa Geologiczne, Warszawa, 38-56.

Czarnecki L., Frankowski R., Organiściak B. \& Skórzak A., 2010. 50 lat pracy geologów na złożu Bełchatów. PGE Górnictwo i Energetyka Konwencjonalna SA Oddział Kopalnia Węgla Brunatnego Bełchatów, Dział Geologiczny.

Gotowała R. \& Hałuszczak A., 2002. The Late Alpine structural development of the Kleszczów trough (Central Poland) as a result of a reactivation of the pre-existing, regional dislocation. EGU Stephan Mueller Special Publication Series, 1, 137-150.

International Classification of Coal In-Seam Coals, 1998. UN-ECE ENERGY/1998/9.
Kasiński J., 2002. Atlas geologiczny trzeciorzędowej asocjacji brunatnowęglowej w polskiej części Niecki Żytawskiej: 1:50 000. Państwowy Instytut Geologiczny, Warszawa.

Kozioł W. \& Sośniak E., 2011. Technologia udostępnienia i eksploatacji węgla w Polu Szczerców. Górnictwo i Geoinżynieria, 35, 3, 181-192.

Kwiecińska B. \& Wagner M., 1997. Typizacja cech jakościowych wegla brunatnego z krajowych złóż według kryteriów petrograficznych i chemiczno-technologicznych dla celów dokumentacji geologicznej złóż oraz obsługi kopalń. Centrum PPGSMiE PAN.

Leśniak T., Ratajczak T., Słomka T. \& Wagner M., 2002. Badania jakości węgla brunatnego z otworów rozpoznawczych i piezometrycznych na podstawie norm ISO wraz $z$ oznaczeniem składników dotychczas nie oznaczonych KWB Bełchatów (z uwzględnieniem otworów wykona$n y c h w$ ramach projektu dodatkowych badań uściślenia konturu pola Szczerców). Stowarzyszenie Naukowe im. Stanisława Staszica.

Low Rank Coal Utilization - International Codification System, 2002. UN-ECE/ENERGY/50.

Narkiewicz M. \& Dadlez R., 2008. Geologiczna regionalizacja Polski - zasady ogólne i schemat podziału w planie podkenozoicznym i podpermskim. Przegląd Geologiczny, 56, 5, 391-397.

Peryt T.M. \& Piwocki M., 2004 (red.). Stratygrafia. Cz. 3a: Kenozoik, paleogen, neogen. Budowa Geologiczna Polski, 1, Państwowy Instytut Geologiczny, Warszawa.

Pietraszewski A., 2015. Polskie górnictwo węgla brunatnego w 2014 roku. Węgiel Brunatny, 1, 90, 4-15, [on-line:] http://www.ppwb.org.pl/Static/upload/File/ wegiel_90_1_2015.pdf [access: 06.07.2016].

Szuflicki M., Malon A. \& Tymiński M. (red.), 2016. Bilans zasobów złóż kopalin w Polsce wg stanu na 31 XII 2014 r. Państwowy Instytut Geologiczny - Państwowy Instytut Badawczy, Warszawa, [on-line:] http://surowce.pgi.gov.pl [access: 06.07.2016].

Wagner M., 2001. Zmienność litologiczna osadów trzeciorzędowych w złożu węgla brunatnego „Szczerców”. [in:] Lipiarski I. (red.), Geologia formacji węglonośnych Polski: XXIV Sympozjum: Kraków, 25-26 kwietnia 2001: materiaty, AGH, Kraków, 101-108.

Styrnol B. \& Wagner M., 2007. Zmienność zawartości siarki w węglu brunatnym ze złoża „Szczerców”. [in:]: Lipiarski I. (red.), Geologia formacji węglonośnych Polski: XXX sympozjum: Kraków, 18-19 kwietnia 2007: materiaty, AGH, Kraków, 149-153.

Widera M., 2013. Changes of the lignite seam architecture A case of study from Polish lignite deposit. International Journal of Coal Geology, 114, 60-73.

Widera M., 2016. Genetic classification of Polish lignite deposit: A review. International Journal of Coal Geology, 158, 107-118.

Widera M. \& Hałuszczak A., 2011. Stages of the Cenozoic tectonics in central Poland: examples from the troughs. Zeitschrift der Deutschen Gesellschaft für Geowissenschafte, 162, 203-216.

Widera M., Kasztelewicz Z. \& Ptak M., 2016. Lignite mining and electricity generation in Poland, current state and future prospects. Energy Policy, 92, 151-157. 